\title{
Metode Muhammad Al-Ghazali dalam Menggali Maqasid Alquran
}

\author{
Abdul Mufid \\ STAI Khozinatul Ulum Blora \\ e-mail: nawalmiza@gmail.com
}

\begin{abstract}
This study aims to explore the main milestones of the method used by Muhammad al-Ghazali to reveal the Qur'anic maqasid by answering a number of questions as follows: Does al-Ghazali have a special method in approaching the Qur'anic maqasid? If it turns out there really is a special method, what are the advantages and characteristics of the method? What are the main features? How far the method was successfully applied in several studies and studies of the Koran. This research aims to explore the main milestones of the method used by Muhammad al-Ghazali to reveal the Qur'anic maqasid by answering a number of questions as follows: Does al-Ghazali have a special method in approaching the Qur'anic maqasid? If it turns out there really is a special method, what are the advantages and characteristics of the method? What are the main features? How far the method has been successfully applied in several studies and studies of the Koran. The result s showed that al-Ghazali offered five methods to be able to reveal the qur'anic maqasid. First, deep reflection on the qur'anic texts and optimizing reason. Second, the use of two mechanisms at the same time, namely inductive thinking and analysis, and tracking various texts and signs that indicate the existence of maqasid. Third, a thorough reading of the revelation texts so that they are holostic, not literal and sectarian. Fourth, always mingle with the Koran while interrogating the verses to explore the depth of their meaning. Fifth, devoting the ability to produce figh of reality
\end{abstract}

Keywords: Qur'anic Studies, Muhammad al-Ghazali, the Qur'anic Maqasid

\begin{abstract}
Abstrak
Penelitian ini bertujuan menggali tonggak utama dari metode yang digunakan Muhammad al-Ghazali untuk mengungkap maqasid Alquran dengan menjawab sejumlah pertanyaan sebagai berikut: Apakah alGhazali memiliki metode khusus dalam mendekati maqasid Alquran? Bila ternyata memang ada metode khusus, apa kelebihan dan karakteristik metodenya itu? Apa saja fitur utamanya? Sejauhmana metode itu berhasil diterapkan dalam beberapa riset dan kajiannya terhadap Alquran?. Hasil penelitian menunjukkan bahwa al-Ghazali menawarkan lima metode untuk dapat menyingkap maqashid Alquran. Pertama, perenungan yang mendalam atas teks-teks Alquran dan mengoptimalkan akal. Kedua, penggunaan dua mekanisme sekaligus, yakni berpikir induktif dan analisis, serta melacak berbagai teks dan tanda yang menunjukan adanya maqasid. Ketiga, pembacaan menyeluruh terhadap teks-teks wahyu sehingga holistik, tidak literal dan sektarian. Keempat, selalu bercengkerama dengan Alquran sembari menginterogasi ayatayatnya untuk mengeksplorasi kedalaman maknanya. Kelima, mencurahkan kemampuan untuk memproduksi fikih realitas.
\end{abstract}

Kata Kunci: Studi Alquran, Muhammad al-Ghazali, Maqasid Alquran

\section{Pendahuluan}

Al-Qur'an merupakan petunjuk dan

pedoman bagi umat manusia dalam menghadapi segala persoalan hidup dan kehidupannya sepanjang zaman, yang tak

layu oleh waktu dan tak lekang oleh zaman, 
serta - meminjam istilah Quraish Shihab dapat berdialog dengan seluruh generasi manusia, guna memperoleh kebahagiaan hidup di dunia maupun akhirat.

Abdullah Darâz dalam al-Nabấ al'Azîm menggambarkan al-Qur'an sebagai batu intan yang setiap sudutnya memancarkan cahaya berbeda. Dengan demikian, Alquran merupakan kitab suci yang memiliki muatan multi-perspektif. ${ }^{1}$

Sebagai petunjuk dalam kehidupan umat Islam, al-Qur'an tidak hanya cukup dengan membaca dengan suara yang indah dan fasih, tetapi selain memahami harus ada upaya konkret dalam memeliharanya. Alquran tidak boleh dibiarkan begitu saja sebagai koleksi atau apapun nama dan bentuknya, tanpa penjagaan dan pemeliharaan yang serius dari umatnya. ${ }^{2}$

Keistimewaaan yang dimiliki Alquran tidak mengandung makna bahwa itulah tujuan diturunkan Alquran kepada manusia. Terlebih jika dimaknai Alquran diturunkan untuk menampakkan ketidaksanggupan manusia untuk menandingi kehebatan Alquran. Membatasi fungsi penurunan Alquran seperti ini sangat

${ }^{1}$ Wahyudi, Tafsir Sufi: Analisis Epistemologi Ta'wil al-Ghazali dalam Kitab Jawahir al-Qur'an, jurnal Ushuluddin, Vol. 26, No. 1 (Januari-Juni, 2018), 45.

2 Ali Akbar dan Hidayatullah Ismail, Metode Tahfidz al-Qur'an di Pondok Pesantren Kabupaten Kampar, jurnal Ushuluddin, Vol. 24, No. 1 (Januari-Juni, 2016), 92. bertolak belakang dengan visi utamanya yaitu membawa petunjuk bagi makhluk hidup. ${ }^{3}$

Diakui bahwa akses menuju kebenaran ilmiah di berbagai bidang ilmu membutuhkan pendekatan yang jelas dan akurat berdasarkan aturan ilmiah dan prosedur yang diterapkan, mengidentifikasi langkah-langkah awal dan mengeksplorasi hasilnya. Jika tidak demikian, maka yang akan terjadi adalah kesia-siaan dari absurditas. Oleh karena itu sebuah pemikiran apapun akan bermanfaat dan berpengaruh bila disertai dengan metode.

Perbincangan seputar tujuan pokok syariah (maqâshid al-syarî'ah) menjadi isu penting dan populer beberapa dekade terakhir ini. Terutama melalui proyek pemikiran maqâshid yang dikembangkan di Magribi melalui beberapa tokohnya seperti Thâhir ibn 'Âsyûr, 'Alâl al-Fâsi, Raysûnî, dan lain sebagainya. Kajian tentang pokok syariah ini dalam perkembangannya bergeser pada kajian tentang tujuan pokok Alquran atau dikenal dengan maqâshid Alquran. Bila maqâshid al-syarî’ah lebih menfokuskan diri pada pemahaman hukum Islam, maka mâqâshid Alquran berupaya

3 Syahrul Rahman, Pro Kontra I'jaz 'Adady dalam alQur'an, jurnal Ushuluddin, Vol. 25, No. 1 (Januari-Juni, 2017), 36. 
memahami konsep, aturan, dan tafsir Alquran. Ini artinya, cakupan mâqâshid Alquran melampaui persoalan hukum yang hanya menjadi bagian kecil dari Alquran.

Kajian tentang mâqâshid Alquran merupakan isu lama yang hingga kini masih menjadi perhatian pemikir Muslim kontemporer. Bahkan tidak sedikit kajian seputar mâqâshid Alquran menjadi bagian yang tidak terpisah dari kajian maqâshid alsyarîah kontemporer yang belakangan menjadi tren baru di dalam kajian Alquran. Apa yang kemudian dikenal dengan tafsir maqâshî̀î menjadi tren dalam kajian Alquran. Sebagai sebuah tren, kajian tafsir maqâshîdî digunakan untuk membaca isu-isu kontemporer dalam kajian Alquran, tidak terkecuali isu kebebasan beragama. ${ }^{4}$

Maqasid Alquran sangat erat kaitannya dengan tafsir. Sebab tafsir merupakan upaya untuk melakukan identifikasi terhadap kandungan Alquran dengan teliti dan cermat. Jalaludin as-Suyuti mendefinisikan tafsir dengan disipin ilmu yang berfungsi memahami Kitabullah yang diturunkan Allah kepada Nabi Muhammad SAW dengan menjelaskan maknanya dan

\footnotetext{
4 Ah. Fawaid, Maqasid al-Qur'an dalam Ayat Kebebasan Beragama Menurut Penafsiran Thaha Jabir al-'Alwani, jurnal Madania, Vol. 21, No. 2, (Desember 2017), 113-114.
}

mengambil kesimpulan hukum. ${ }^{5}$ Sementara itu maqasid Alquran merupakan basis dan arah dalam menafsirkan Alquran.

Metode dalam bahasa Arab disebut manhaj. Kata manhaj itu sendiri secara etimologi memiliki banyak makna, di antaranya sebagaimana dijelaskan dalam Lisan al-'Arab bahwa kata manhaj bentukan dari kalimat fi'il (kata kerja) nahaja dan anhaja. Seperti dalam kalimat anhaja at-tariqu yang artinya jalan itu terang dan jelas. Sementara itu manhaj dan minhaj berarti jalan yang jelas dan lurus. ${ }^{6}$ Disebutkan dalam al-Mu'jam al-Wasit, bahwa asal kata manhaj adalah nahaja, seperti dalam contoh nahaja fulanun al-amra nahjan yang artinya fulan telah menjelaskan persoalan. Ada pula contoh kalimat nahaja at-tariqa yang artinya menempuh jalan atau cara. Sementara itu kata nahjun artinya menempuh jalur yang jelas. $^{7}$

Secara terminologi, manhaj adalah jalur yang diambil oleh peneliti untuk mencapai tujuan, atau metode berinteraksi dengan topik-topik yang disajikan untuk penelitian dan kajian. Metode merupakan pola pemikiran dan pengalaman yang

\footnotetext{
5 Jalaludin as-Suyuti, al-Itqan fi Ulum Alquran, (Kairo: Dar as-Salam, 1998), 174.

6 Ibnu Manzur, Lisan al-'Arab, vol. 14 (Beirut: Dar Sadir, 2003), 366.

7 Akademi Bahasa Arab di Kairo, al-Mu'jam alWasit (Beirut: Dar al-Hadis, 1980), 957.
} 
berhubungan dengan beberapa bidang pengetahuan humanis yang berjalan secara teratur menuju hasil tertentu. Abdurrahman Badawi mendefinisikan manhaj dengan seni mengorganisir serangkaian ide dengan benar, baik untuk mengungkapkan kebenaran ketika kita tidak tahu, atau menunjukkannya kepada orang lain ketika kita mengetahuinya. ${ }^{8}$ Mahdi Fadlullah mendefiniskan manhaj dengan alat yang digunakan peneliti untuk mencapai tujuan dan menemukan kebenaran atau mendapatkan pengetahuan. ${ }^{9}$

Ilmu-ilmu keislaman yang muncul dalam lingkup Alquran ${ }^{10}$ dan bercabang ke banyak spesialisasi, seperti tafsir, fikih, kalam, tasawuf, dan lainnya memiliki metode-metode tertentu dalam berinteraksi dengan Alquran. Oleh sebab itu masingmasing keilmuan tersebut memiliki metode khusus dalam mengkaji Alquran maupun ulumul qur'an. Kebanyakan metode tersebut berpijak dan hanya membatasi pada orientasi ilmiah, serta mencoba dengan berbagai cara untuk menaklukkan teks-teks Alquran. Maka dari itu institusi

8 Abdurrahman Badawi, Manahij al-Bahs al-'Ilmi, cet. III (Kuwait: Wakalah al-Matbu'ah, 1977), 4.

${ }_{9}$ Mahdi Fadlullah, Usul Kitabah al-Bahs wa Qawa'id at-Tahqiq, cet. II (Beirut: Dar at-Tali'ah, 1998), 12.

${ }_{10}$ Muhammad Sami an-Nasyar, Nasy'ah al-Fikr alFalsafi fi al-Islam, cet. V, vol. 1 (Kairo: Dar al-Ma'arif, 1971), 295. ahli hadis misalnya, hanya membatasi misinya dan membatasi minatnya pada ilmu-ilmu hadis saja, jauh dari pandangan yang holistik terhadap nilai-nilai Islam. Begitu pula institusi fikih yang hanya berkonsentrasi pada lingkup ibadah dan hal-hal yang terkait dengannya, sehingga dari institusi tersebut dapat dijadikan bingkai untuk kegiatan rasionalnya dan jarang sekali melenceng jauh dari bidang fikih. ${ }^{11}$

Dikatakan sebagai sebuah kecerobohan, bila di era modern seperti sekarang ini tidak dapat mengungkap teori maqasid Alquran dalam sejarah ilmu-ilmu keislaman dan tidak pula menemukan metode tertentu untuk mendeteksi dan memanfaatkan maqasid tersebut. Hal itu berbanding terbalik dengan kalangan ulama sebelumnya dan para reformis yang telah berupaya keras meletakkan metodologi ilmiah dan kontrol metodologis yang berguna untuk mengendalikan penelitian di dalamnya, serta menekankan perlunya pendekatan ilmiah yang jelas untuk berinteraksi dengan Alquran, dan di antara para ulama yang menjadikan maqasid Alquran sebagai bagian terbesar dari

11 Muhammad al-Ghazali, Kaifa Nata'amalu ma'a Alquran, cet. VII (Kairo: Nahdah, 2005), 37-38. 
perhatiannya adalah syaikh Muhammad alGhazali.

Minat dan konsentrasi Muhammad al-Ghazali yang jelas terhadap maqasid Alquran dan berbagai masalah yang terkait dengannya, serta keyakinan al-Ghazali pada kebutuhan umat yang mendesak untuk menemukan dan memanfaatkan maqasid Alquran, membuat Muhammad al-Ghazali harus berbanding lurus dengan fokus pada perumusan metode yang ideal untuk mengungkap dan memantau maqasid tersebut. Menurut al-Ghazali, di dalam hadis terdapat ruang besar yang memuat metode untuk mengungkap maqasid Alquran. Muhammad al-Ghazali meyakini bahwa maqasid yang penarikan konklusinya berasal dari Kitabullah membutuhkan adanya metode khusus yang sepadan dalam hal karakter antara maqasid dengan Alquran, konsisten dengan dimensinya, dan sesuai dengan kehendak Allah. Hal ini pernah diungkapkan Taha Jabir al-'Ulwani, bahwa metodologi itu layaknya penyusun pengetahuan yang mengembalikan hal banyak kepada hal yang satuan, mutasyabih (masih samar) dikembalikan kepada yang muhkam (jelas). Metodologi membutuhkan kesadaran kognitif tentang metode-metode berinteraksi dengan teks-teks yang berpijak dari pengetahuan metodologis. ${ }^{12}$

Metode Muhammad al-Ghazali dalam menggali maqasid Alquran berpijak pada sejumlah mekanisme:

1. Perenungan yang mendalam, gagasan yang gigih dalam merenungi teks-teks Alquran, serta memfungsikan akal untuk mengungkap rahasia dan misterinya.

2. Muhammad al-Ghazali memberlakukan dua mekanisme, yakni berpikir induktif dan analisis, serta melacak berbagai teks dan tanda yang menunjukkan adanya maqasid.

3. Muhammad al-Ghazali berpegang pada pembacaan menyeluruh terhadap teks-teks wahyu yang melampaui semua bentuk pembacaan yang tidak mampu menemukan universalitas wahyu, sebagaimana pembacaan yang tidak holistik, literal, dan sektarian serta bentuk-bentuk pembacaan lainnya yang salah memahami dimensi maqasid bagi misi kerasulan.

4. Sehari-hari bercengkerama dengan Alquran sembari menginterogasi ayat-ayatnya untuk mengeksplorasi

12 Taha Jabir al-'Ulwani, Maqasid asy-Syariah, cet. I (Beirut: Dar al-Hadi, 2001), 48. 
kedalamannya dan menyelami makna-maknanya yang samar.

5. Muhammad al-Ghazali berpijak dari krisis keterbelakangan peradaban yang memukul keras umat atas sebab kehilangan spirit maqasid, mencurahkan kemampuan untuk menarik konklusi penyebab tergelincirnya umat dari teks-teks wahyu, atau dengan term yang lebih familier disebut fikih realitas.

Berpijak dari sejumlah mekanisme di atas, maka Muhammad al-Ghazali menolak untuk mengadopsi metode ilmuilmu keislaman klasik, seperti metode yang ditempuh para ulama usul fikih, fukaha, ahli bahasa, ahli ilmu kalam, para ulama tasawuf dan lain sebagainya. Muhammad alGhazali berpandangan bahwa terdapat perbedaan yang sangat luas antara metode ilmu-ilmu keislaman klasik dengan tuntutan yang dikehendaki maqasid Alquran yang memiliki karakteristik khusus. Pada konteks inilah Muhammad alGhazali mengkritik metode-metode klasik yang dianggapnya tidak memenuhi tuntutan maqasid
Alquran, tidak berpandangan yang komprehensif, dan tidak berpengetahuan yang mendalam mengenai berbagai dimensi wahyu.

Artikel ini penulis dedikasikan sebagai bentuk upaya untuk menyingkap rambu-rambu besar yang dijadikan tendensi Muhammad al-Ghazali dalam menggali metode untuk mengungkap maqasid Alquran dengan menjawab sejumlah research question, di antaranya apakah Muhammad al-Ghazali memiliki metode khusus untuk mendekati maqasid Alquran? Apabila alGhazali memang mempunyai metode khusus, apa keistimewaan dan karakteristiknya? Apa ramburambu besarnya? Sebatas mana metode al-Ghazali dapat diaplikasikan dalam riset dan kajian Alquran?

\section{Al-Ghazali dan Review Terhadap} Metodologi Riset Ilmu-ilmu Keislaman Klasik

Muhamad al-Ghazali menghapus secara total metode-metode yang dipakai para ulama klasik lintas keilmuan; ilmu 
fikih, bahasa, kalam, tasawuf, tafsir, dan ulumul qur'an. ${ }^{13}$ Muhammad al-Ghazali meyakini bahwa mayoritas ulama melupakan topik maqasid Alquran, berlebihan dalam memberikan perhatian terhadap hal-hal yang parsial, membatasi keluasan ruang gerak Alquran dari berbagai sudut (pemikiran atau kehidupan), dan melarang umat Islam untuk menembus horizon yang lainnya. Ia mengatakan:

"Saya selalu mengikuti dan memikirkan banyak hal yang telah mereka tulis dalam segala disiplin ilmu; ilmu kalam, tasawuf, dan akhlaq. Semoga Allah memberi manfaat kepada saya atas karyakarya para ulama. Hanya saja saya mendapati kenyataan-kenyataan di sini dan di sana. Maka dari itu tidak ada satupun aliran yang saya pegangi, dan saya tak melihat seorang pun yang tanpa dosa."14

Terlepas dari relevansi kritik yang dilontarkan al-Ghazali ini, namun yang perlu digarisbawahi bahwasanya mengesampingkan karya-karya peninggalan ulama masa lalu dan melampauinya secara total serta mengingkari nilai-nilai positif yang ditanamkan, maka akan menghasilkan nalar-nalar Islam yang berbahaya. Itulah

\footnotetext{
13 Muhammad al-Ghazali, Kaifa Nata'amalu ma'a Alquran, cet. 7 (Kairo:Nahdah Misr li at-Tiba'ah, 2005), 35.

${ }^{14}$ Muhammad al-Ghazali, Sirru Ta'akhkhur al-'Arab wa al-Muslimin (Kairo: Dar ar-Rayyan li at-Turas, 1987), 73.
}

sebenarnya yang selalu diingatkan oleh Umar 'Abid Hasanah kepada al-Ghazali disaat bertanya kepadanya mengenai media-media keamanan yang dapat menjamin kita mampu menembus kebenaran bersama Alquran secara langsung tanpa melibatkan karya-karya ulama sebelumnya. Umar 'Abid Hasanah berujar:

"Bagaimana kita mendapatkan manfaat dari metode-metode itu untuk kembali kepada sumber yang asli (Alquran). Apakah warisan metodologis ini wajib bagi kita, padahal bukankah ia merupakan bentuk ijtihad yang mewujudkan berbagai dimensi yang bagus untuk mencapai visi Alquran? Apakah kita boleh melompatinya dari atas dan kita berinteraksi langsung dengan teks? Jadi sebenarnya apa sarana keamanan bagi kita untuk berinteraksi dengan teks?"15

Penulis memandang bahwa membesar-besarkan kritik terhadap hasil ijtihad ulama masa lalu itu boleh, namun tidak bisa diterapkan untuk hasil ijtihad semua bidang keilmuan. Memang betul berlebih-lebihan dalam kritik dapat menguras tenaga pelakunya pada banyak hal yang parsial dan berurusan dengan masalah imajiner yang mungkin tidak akan terjadi sama sekali dalam realitas. Itulah

\footnotetext{
${ }^{15}$ Al-Ghazali, Kaifa Nata'amalu ma'a Alquran, 46.
} 
yang diisyaratkan al-Ibrahimi dalam pernyataannya:

“Sayang sekali kampanye-kampanye yang menyeru kekerasan dan menganggap jihad, namun tanpa musuh. Sungguh keterlaluan kegembiraan di atas kegembiraan, padahal jelas cara perolehannya tidak melalui ekspansi maupun raihan kemenangan. Sangat menyesalkan, bagi kecerdasan yang hampir dapat menyembuhkan penghalang yang tak terlihat, seperti kecerdasan Abu Bakar al-Baqilani, Fakhrudin ar-Razi, Abu Huzail, dan Ibu Mu'allim. Telah hilang suatu kemanfaatan yang takkan kembali." 16

Adapun hal lain yang mendesak untuk dijawab adalah pertanyaan apakah metode-metode yang berbeda dan beragam itu ketika awal dicetuskan, tujuan jangka panjangnya adalah mendekati maqasid Alquran? Menurut penulis, fakta yang tidak dapat diabaikan adalah ketika metodemetode itu dibuat, maka ia memiliki bidang-bidang tertentu tempat bergeraknya, sehingga kita tidak mampu mencatat berbagai kekurangan dan memintanya agar keluar dari bidang garapannya untuk selanjutnya dipaksakan agar mencari maqasid Alquran. Perlu dicatat pula,

16 Muhammad Basyir al-Ibrahimi, Asar al-Imam Muhammad al-Basyir al-Ibrahimi, cet. I (Beirut: Dar al-Gharb al-Islami, 1997), 167. bahwa kebanyakan ijtihad ulama masa lalu itu sesuai konteks peradaban saat itu.

Menurut penulis, disinilah bisa dikatakan bahwa berbagai ijtihad ulama tempo dulu belum mampu mengungkap maqasid Alquran. Ketidakmampun mereka bukan berarti akal pikiran para ulama saat itu belum mampu menciptakan metodemetode khusus, melainkan memang belum ada kebutuhan yang menuntut diciptakannya metode baru. Bahkan karena kebutuhan pada saat itu tidak memerlukan metode seperti itu. Inilah yang membuatnya tertinggal dalam kemunculannya di era modern, di mana kebutuhan untuk itu kuat dan mendesak karena adanya krisis peradaban yang mencekik sehingga umat mencari sendiri jalan keluar darinya. Hanya saja umat tidak menemukan cara lain selain mengungkap maqasid dan mengaktifkannya untuk menghindari ketergelinciran.

Fitur Metode al-Ghazali dalam Mengungkap Maqasid Alquran

Dengan mengikuti tulisan-tulisan Muhammad al-Ghazali, nampak keseriusan dan ketertarikannya yang mendalam tentang pendekatan yang jelas dan ketat untuk mengakses dunia maqasid Alquran, 
dan meneliti dengan perangkat ilmiah serta syarat-syarat metodologis yang dapat menjamin tercapainya hasil yang diinginkan. Maqasid tersebut menurut alGhazali memiliki metode khusus yang berpijak pada pembacaan Alquran secara komprehensif sebagai satu kesatuan yang menyeluruh dan terintegrasi serta saling bahu membahu antara satu dengan yang lainnya.

Beberapa pondasi dasar yang melatarbelakangi terbentuknya metode dan pemikiran al-Ghazali dalam mendekati Alquran adalah sebagai berikut:

1. Berpegang pada pandangan yang universal dan komprehensif.

Termasuk pondasi terpenting yang menjadi dasar pendekatan al-Ghazali adalah keberpihakannya pada pembacaan teks-teks wahyu secara universal dan komprehensif yang melampaui semua bentuk pembacaan yang tidak mampu mengenali keuniversalan wahyu. Secara aksiomatis, setiap metode itu lahir dan berasal dari landasan filosofis dan intelektual yang menggambarkan wataknya, serta memetakkan batas-batas dan keterkaitan yang melingkupinya. Sementara itu pandangan yang universal dan komprehensif adalah landasan teoretis dan intelektualis bagi metode al-Ghazali tersebut. Maka dari itu menurut al-Ghazali, tidak mungkin dapat mendekati maqasid Alquran tanpa berpijak dari persepsi ini, karena pandangan yang universal dan komprehensif itulah yang memungkinkan al-Ghazali untuk bergerak ke arah ini.

Jika diasumsikan al-Ghazali berpijak dari pandangan yang parsial dan persepsi yang bersifat lokal tentang Alquran, maka al-Ghazali tidak akan berhasil mendekati maqasid Alquran. Karena pandangan yang parsial biasanya akan mengarah pada banyaknya pendapat dan hukum, serta kontradiksi dan inkonsistensi. Abdul Majid an-Najjar mengungkapkan:

"Apabila sebuah pemikiran didasarkan pada pertimbangan yang parsial, maka seorang pemikir akan menemukan dirinya bertentangan dengan orang lain. Karena ia akan tetap menjadi tahanan pandangan parsialnya. Sementara pada kesempatan yang sama, orang lain juga mengeluarkan keputusannya yang parsial pula. Sehingga masingmasing berakhir di lembah pertikaian yang tidak bisa bertemu satu sama lain. Oleh karena itu tertahannya akal dalam hal-hal yang parsial adalah sebuah hasil yang negatif, tidak hanya dalam tataran pengetahuan saja, melainkan juga pada level sosial. Beda lagi bila 
mendasarkan pada pertimbangan yang komprehensif."17

Alquran telah memperingatkan terhadap pembacaan dispersif yang menghilangkan teks-teks suci dari sisi nilai, dampak, dan efektifitasnya dalam kehidupan manusia. Alquran QS. Al-Hijr: 90-91 juga telah memberitahu bahwa orangorang musyrik ketika menyetujui sebagian sesuatu, sementara sebagian musyrik lainnya menentang, maka mereka tidak mendapat manfaat apapun. Abu as-Sa'ud mengungkapkan:

"Penyebutan parsialisasi Alquran dengan kata $t a^{\prime}$ dhiyah, yang makna aslinya adalah memisahkan anggota tubuh yang masih melekat dan bernyawa dengan tujuan untuk menghilangkan nyawanya dan membatalkan namanya, bukan murni membagi-bagi atau memisahkan, menunjukkan sempurnanya keburukan yang telah mereka perbuat terhadap Alquran."18

Mengacu pada persepsi inilah Muhammad al-Ghazali mengkritik dengan sangat pedas terhadap metode ilmiah para ulama klasik yang tenggelam dalam

17 Abdul Majid an-Najjar, Maqasid Alquran fi Bina al-Fikr al-'Umrani, jurnal Islamiyah al-Ma'rifah, Vol. 89, No. 33 (2017), 88.

18 Muhammad bin Muhammad Abu as-Sa'ud, Irsyad al-'Aql as-Salim ila Mazaya Alquran al-Karim (Tafsir Abi as-Sa'ud), vol. 5 (Beirut: Dar Ihya' at-Turas, t.t.), 92. pencarian hal-hal parsial dan absen dari pandangan holistik tentang sumber-sumber wahyu, yakni Kitabullah dan sunnah, serta merupakan penyebab utama perpecahan dan manipulasi di antara umat Islam. Abdul Majid an-Najjar mengungkapkan:

"Mungkin sebagian besar yang dialami umat ini yang berupa perpecahan, banyak cobaan, dan sulit untuk bangkit, adalah muncul dari sikap-sikap yang didasarkan pada dalil-dali syar'i yang parsial, tanpa ada pandangan yang komprehensif."19

\section{Al-Ghazali mengatakan:}

"Ketertarikan pada hal-hal yang kontroversial (khilafiyah) adalah termasuk warna dari karakter masa kanak-kanak yang suram, dan termasuk penyimpangan yang merelakan diri berpisah dengan keluarganya dari bidang kebenaran yang banyak beban menuju bidang lain yang tidak sulit dan tidak ada beban tugas berat. Sesungguhnya orang-orang ahli Alquran mengkhianatinya dengan pengkhianatan yang tidak bermoral. Mereka meninggalkannya ketika mereka senang dengan kata-kata palsu dan kontroversi yang konyol. Mereka tenggelam dalam keadaan koma yang aneh dari beberapa pembahasan yang tidak diketahui oleh ulama generasi awal. Dan jika mereka mengetahuinya, mereka tidak akan pernah berhasil, juga

19 Abdul Majid an-Najjar, Maqasid Alquran fi Bina al-Fikr al-'Umrani, 89. 
tidak dapat mendirikan
peradaban." 20

Dari situlah al-Ghazali menyeru dan mendesak untuk melampaui bentukbentuk ijtihad dan pembacaan; parsial, literal, dan doktrinal, yang dapat menyebabkan kesalahan dalam memahami dimensi maqasid Alquran dan mengakses dari zahirnya teks menuju maksud dan tujuannya, bergantung pada konsepsi holistik yang akan berkontribusi kuat untuk memberi pencerahan kepada umat mengenai tempat-tempat yang negatif, dan membimbingnya ke jalan yang paling efektif untuk keluar dari krisis peradabannya.

2. Menembus spirit Alquran dan melampaui bentuk ijtihad formal

Pendekatan maqasid terhadap Alquran mengharuskan bisa menembus ke dalam jiwanya, menyebur ke kedalamannya, dan mengkaji berbagai problematika dan permasalahan dalam kerangka spirit Alquran. Spirit Alquran juga membentuk dasar intelektual dan teoretis untuk metode ini, dan pendekatan yang berhasil untuk maqasid Alquran harus diwujudkan dalam masalah ini. Pandangan

${ }^{20}$ Muhammad al-Ghazali, Turasuna al-Fikri fi Mizan asy-Syar'i wa al-'Aql, cet. 5 (Kairo: Dar asy-Syuruq, 2003), 710. yang holistik, visi yang komprehensif, dan menembus spirit Alquran merupakan dua sisi dari mata uang yang sama, yang menetapkan kerangka teoretis bagi metode pendekatan maqasid al-Ghazali.

Atas dasar itulah banyak dijumpai dalam beberapa tulisan Muhammad alGhazali yang menekankan perlunya mematuhi semangat Alquran dan berpijak darinya dalam rangka pendekatan terhadap poros-poros Alquran, maqasid umum, dan keseluruhan dimensi Alquran. Al-Ghazali mengarahkan agar merujuk ke era Nabi dan fase sejarah setelahnya yang mana umat Islam terus menerus berhubungan dengan Kitabullah secara sadar dan menetapi arahannya. Oleh karena itu efek Alquran dalam kehidupan mereka sangat mengesankan. Al-Ghazali mengungkapkan:

"Ketika orang-orang Arab membaca Alquran, mereka secara otomatis berubah menjadi umat yang mengerti syura dan membenci tirani menjadi umat yang berkeadilan sosial dan tidak berlaku sistem kasta menjadi umat yang membenci diskriminasi rasial, membenci moral kesombongan dan keangkuhan. Umat yang memperkenalkan peradaban baru bagi dunia. Umat yang menghidupkan kembali humanisme dan mengangkat statusnya." 21

${ }^{21}$ Al-Ghazali, Kaifa Nata'amalu ma'a Alquran, 28. 
Inilah yang membuat al-Ghazali berani mengkritik arah formal yang berkaitan dengan membaca Alquran secara tartil, menetapkan aturan-aturan dalam membacanya, menetapkan tajwid tempat keluarnya huruf, melepas semua kesedihan dengan membaca Alquran, mencurahkan semua usaha untuk membuat syakal (harakat),22 menghafal semua qiraat (bacaan), melantunkan kata demi kata dan kalimat demi kalimat dalam Alquran, mengaitkan Alquran dengan pemakaman dan acara-acara, duduk untuk membaca atau mendengarkan layaknya seseorang yang duduk untuk mendengarkan musik dan lagu sembari mengingat bahwa tragedi umat Islam dalam hubungan mereka dengan Alquran adalah karena mereka tidak menyadari apa yang mereka baca Alquran. Al-Ghazali mengungkapkan:

"Hikmahnya sangat jauh antara kata-kata yang kita ucapkan dan arti yang menyertainya. Berapa banyak dari kita bagaikan burung beo yang dari mulutnya mengalir kata-kata hebat. Namun jika Anda pergi mencari fakta-faktanya di hati orang-orang tersebut, maka Anda menemukan kekosongan atau kekontrasan. Sayangnya, sebagian besar perlakuan kita terhadap Tuhan berasal dari mata jahat ini." 23

22 Al-Ghazali, Kaifa Nata'amalu ma'a Alquran, 15.

${ }^{23}$ Muhammad al-Ghazali, Raka'iz al-Iman Baina al'Aql wa al-Qalb (Kairo: Dar asy-Syuruq, 2001), 107-108.
Faktor-faktor inilah dan faktor lainnya yang memalingkan dari tujuan utama, yaitu refleksi dan perenungan terhadap Alquran. Praktik-praktik formal yang menguras umat dari upaya-upaya besar sepanjang sejarahnya yang panjang telah membuat umat Muslim kurang mempertimbangkan ayat-ayat Alquran secara optimal, melihat maknanya, dan mengantisipasi cakrawalanya.

3. Pembacaan yang mendalam terhadap teks dan melampaui pembacaan yang literal

Sisi ketiga dari beberapa sisi metode al-Ghazali dalam aspek teoretis dan konseptualnya adalah perlunya melanjutkan pemahaman yang mendalam tentang teks dan melampaui semua pembacaan literal yang menghalangi akses menuju dimensi Alquran secara komprehensif dan tujuan umum teks.

Al-Ghazali sendiri sering ditemukan berdiri bersama para pengikut tren ini sembari menganggap cacat mereka karena pandangan mereka yang sempit, kedangkalan pemikiran mereka, serta pengabaian mereka terhadap makna utama teks dan maksud terdalamnya. Padahal teks itu sendiri cakrawalanya yang luas, dan 
jangkauan pandangannya jauh ke depan sehingga mampu menghubungkan antara yang ada sebelum teks datang dan setelah teks ada. Itulah makna yang terkandung dalam ucapan asy-Syatibi berikut ini:

"Ketahuilah, jika Allah menjauhkan pemahaman atau keilmuan dari suatu kaum, maka penyebabnya adalah karena mereka hanya melihat hal yang tampak dan tidak mempertimbangkan apa yang dimaksud oleh-Nya. Sebaliknya, jika Allah memberikan pengetahuan kepada suatu kaum, maka hal itu dikarenakan mereka memahami kehendak Allah dalam khitab-Nya. Dan kehendak Allah tersebut tidak tampak dari luar." 24

Menurut al-Ghazali meneliti masalah ini mudah dilacak. Selama beberapa dekade, al-Ghazali terus menerus menyerukan perlunya refleksi yang mendalam terhadap teks-teks Alquran. Menurutnya pula refleksi yang mendalam pada teks Alquran adalah satu-satunya cara yang dapat membuka cakrawala luas bagi umat. Al-Ghazali menegaskan bahwa orang-orang yang menjadi tahanan teks dan berinteraksi bersamanya secara literal, maka mereka tidak dapat memahami implikasi dan maqasid dari teks, dan pada saat yang sama mereka tidak dapat membaca realitas

${ }^{24}$ Asy-Syatibi, al-Muwafaqat fi Usul al-Figh, vol. 4 (Beirut: Dar al-Ma'rifah, t.t.), 214. di sekitarnya dan juga tidak dapat menempatkan teks sesuai kebutuhan teks dan kemaslahatan umat. Semakin mereka lemah dalam memahami isi dan tujuan teksteks wahyu, maka mereka akan menjadi lebih terikat pada formalitas-formalitas, dan akan mereduksi agama di dalamnya. ${ }^{25}$

Dalam konteks ini, pada banyak kesempatan Syaikh al-Ghazali telah memanggil dan menyeru secara tegas bahwa tidak ada sunnah tanpa fikih, dan teks yang ada di tangan kita mencerminkan pandangannya yang komprehensif dan mendalam tentang masalah ini. Al-Ghazali mengungkapkan:

"Anda lihat orang-orang bodoh datang mendekati sunnah, tetapi ia sejatinya jauh dari sunnah. Itulah contoh orang yang mendistorsi teks dari posisinya yang semula." 26

Berdasarkan keterangan di atas, maka dapat diambil kesimpulan bahwa kerangka teoretis dan intelektual bagi metode al-Ghazali dalam memahami maqasid Alquran itu didasarkan pada tiga pilar yang membentuk landasan intelektualnya. Oleh karena itu pandangan

${ }^{25}$ Mahmud 'Abduh, Muhammad al-Ghazali Da'iyah an-Nahdah al-Islamiyyah, cet. 1 (Beirut: Markaz al-Hadarah li Tanmiyah al-Fikr al-Islami, 2009), 89.

${ }^{26}$ Muhammad al-Ghazali, Ma'a Allah Dirasat fi ad$D a^{\prime}$ wah wa ad-Du'ah, cet. 4 (Damaskus: Dar al-Qalam, 2000), 192. 
yang universal dan komprehensif, kemampuan untuk menembus spirit Alquran, mampu melampaui ijtihad-ijtihad formal, memiliki kekuatan pemahaman, dan mampu melampaui pembacaan yang literal, semuanya membentuk kerangka teoretis bagi metodenya. Dan metode apapun dalam pandangan al-Ghazali bila masih terpaku pada aturan-aturan dan prinsip-prinsip formal, maka tidak akan berhasil mencapai maqasid Alquran.

\section{Perangkat-perangkat Prosedural Bagi Metode al-Ghazali dalam Mendekati Maqasid Alquran}

Melalui pembacaan terhadap karya-karya Muhammad al-Ghazali, dapat dilihat sejumlah perlengkapan dan prosedur metodologis yang dianggap alGhazali sebagai pondasi metodenya. Oleh karena itu berkomitmen pada sejumlah perlengkapan dan prosedur metodologis ini memungkinkan peneliti untuk membuat pendekatan yang benar terhadap maqasid Alquran. Sebaliknya, tidak adanya komitmen terhadap sejumlah perlengkapan dan prosedur metodologis, baik sebagian maupun seluruhnya, akan membuat pendekatan ini tidak cukup sistematis. Hal inilah yang ditegaskan Ahmad Salam yang berpendapat bahwa faktor terbesar yang menimpa kaum muslimin sepanjang sejarah adalah menyia-nyiakan pandangan metodologis untuk pembangunan yang berperadaban yang menempatkan mereka berada dalam pandangan parsial, ambiguitas metode, dan perannya tumpang tindih, serta berikutnya hilangnya efektivitas. ${ }^{27}$ Karena dimensi metodologis menurut banyak pengkaji adalah inti dari setiap upaya perubahan, esensial, dan fundamental. Tanpa itu akan berubah menjadi perbedaan dan kekacauan yang tidak berarti. 28

1. Tafsir tematik menjadi pengantar menuju pendekatan maqasid

Tafsir tematik termasuk ilmu baru yang membahas tentang berbagai masalah dan maqasid Alquran. Termasuk karakteristik tafsir tematik yang paling menonjol adalah menghimpun unsur-unsur tema yang sama berdasar ektensi Alquran. Mustafa Muslim mendefinisikan tafsir tematik dengan ilmu yang berurusan dengan permasalahan-permasalahan yang sesuai dengan maqasid Alquran melalui

27 Ahmad Salam, al-Ab'ad al-Manhajiyyah li al-'Amal al-Islami, jurnal al-Ummat, vol. 67, (Maret, 1986), 26.

${ }_{28}$ Tib Burghus, al-Ab'ad al-Manhajiyyah li Isykaliyah at-Taghyir al-Hadari wa Darurah al-Manhaj, cet. 1 (Al-Jaza'ir: Dar al-Yanabi' li an-Nasyr wa al-I'lam, 1993), 9. 
satu surat atau lebih. ${ }^{29}$ Sementara al-Ghazali mendefinisikannya dalam pernyataannya:

“Tafsir tematik memiliki dua tipe baru dalam memberikan pelayanan terhadap Kitabullah. Pertama, melacak permasalahan yang ada di dalam Alquran dan menjelaskannya sesuai perspektif wahyu yang turun selama hampir seperempat abad. Kedua, pandangan yang menetrasi dalam surat yang sama untuk mengetahui poros yang ada di sekitarnya, dan beberapa utas tersembunyi yang menjadikan awalnya sebagai pendahuluan untuk yang terakhir, dan yang terakhir mengkonfirmasi dari yang pertama." Atau dengan kata lain, membentuk gambar yang cepat terhadap fitur-fitur semua surat. ${ }^{30}$

Tafsir tematik merupakan ilmu yang konsen dalam menafsirkan Kitabullah dengan mengamati kesatuan tematik dalam beberapa surat dan ayat, serta merenungkan hubungan di antara ayat dan surat tersebut. Tidak diragukan lagi bahwa terdapat hubungan yang kuat antara tafsir tematik dengan maqasid secara umum. Sebab tafsir tematiklah pintu masuk paling fundamental untuk mengungkap maqasid. Abdul Hamid Mahmud Ghanim mengungkapkan:

"Kajian tematis merupakan metode yang paling mengena dan

${ }^{29}$ Mustafa Muslim, Mabahis fi at-Tafsir al-Maudui, cet. 4 (Beirut: Dar al-Qalam, 2005), 16.

${ }^{30}$ Muhammad al-Ghazali, Turasuna al-Fikri fi Mizan asy-Syar'i wa al-'Aql, cet. 5 (Kairo: Dar asy-Syuruq, 2003), 128. mendalam untuk mengungkap alasan-alasan teks, keterkaitan teks, hikmah dan petunjuk teks, serta dilalahnya dengan menggunakan kacamata Alquran itu sendiri untuk mendapatkan bakat mengenali maqasid Alquran." 31

Al-Ghazali berpendapat bahwa tafsir tematik dapat membantu seorang muslim untuk mengetahui isi Alquran dengan baik, menemukan korelasi tersembunyi dengan menghimpun ayat-ayat dan surat-surat dalam satu konteks, menancapkan dalam benak seorang muslim tentang pandangan yang holistik dan komprehensif, serta menuntunnya sampai tujuan dengan sikap yang Qur'ani. Tafsir tematik ini tidak muncul kecuali bagi orang yang memiliki pengalaman berteman yang lama dan koeksistensi yang permanen kepada Kitabullah dengan disertai keahlian ilmiah dan tulusnya niat. Karena sebuah pengalaman akan mematangkan berbagai permasalahan dan pertanyaan. Sementara keabadian berteman dengan Alquran akan menerangi hidayah dan jawaban-jawaban. Oleh karena itu tidak ada yang mampu dengan tafsir tematik selain seorang alim

31 Abdul Hamid Mahmud Ghanim, at-Tafsir alMaudu'i, jurnal al-Bayan, vol. 165, (Agustus, 2001), 19. 
yang mengamalkan ilmunya dan jujur yang berupaya keras dalam kehidupannya. ${ }^{32}$

Oleh karena itu al-Ghazali mengaitkan serius antara tafsir tematik dengan maqasid Alquran. Ia berupaya keras mengaplikasikan hasil pemahamannya ke dalam realitas umat, menciptakan solusi yang bersumber dari hasil pembacaan terhadap maqasid Alquran, sehingga dalam arena ini al-Ghazali sering melakukan study tour yang diabadikan dalam sejumlah karyanya $^{33}$ bertemakan seputar tafsir tematik dan sebagian problematika Alquran.

2. Penggunaan dua metode, yakni induksi dan analisis untuk mendekati maqasid

Penggunaan mekanisme induksi dan analisis, serta melacak teks-teks dan petunjuk-petunjuk yang berbeda merupakan salah satu perangkat prosedural dalam metode al-Ghazali. Mekanisme induksi menempati posisi istimewa dalam metodenya. Terbukti bahwa al-Ghazali berpegang padanya disaat mengkaji Alquran, menggunakannya dalam melacak

32 Yunus Milal, Manhaj asy-Syaikh Muhammad alGhazali fi Ta'amulihi ma'a Alquran, Disertasi, Universitas alJaza'ir, 2010, 181.

33 Muhammad al-Ghazali, Nahwa Tafirin Maudu'iyyin li Suwar Alquran al-Karim, cet. 4 (Kairo: Dar asySyuruq, 2000). Lihat pula Muhammad al-Ghazali, Nazrat fi Alquran, cet. 5 (Kairo: Nahdah Misr, 2005). bagian-bagian Alquran, mengumpulkan bagian-bagian tersebut, dan menganalisisnya, serta mengeluarkan korelasi-korelasi untuk sampai kepada komprehensifitas yang kompleks dalam membentuk maqasid besarnya. Metode induksi adalah salah satu metode heuristik yang digunakan akal manusia dalam melakukan penarikan konklusi. Hasil dari penarikan kesimpulan dengan cara induksi adalah bergesernya akal dari pandangan parsial ke pandangan universal. ${ }^{34} \mathrm{Hal}$ senada juga dikatakan Ibnu as-Subuki, bahwa metode induksi adalah menetapkan hukum secara umum karena keberadaannya di sebagian besar bagianbagiannya. 35

\section{Al-Ghazali menegaskan bahwa} mengamati maqasid Alquran sangat membutuhkan metode induksi ini untuk membantu pengkaji Kitabullah guna menemukan dan menangkap benang tersembunyi yang menghubungkan antara satu ayat dengan ayat yang lainnya, serta membimbing ke arah pandangan holistik yang menunjukkannya kepada maqasid yang didistribusikan di antara maknanya,

${ }^{34}$ Ismail Husni, Nazariyah al-Maqasid 'Inda al-Imam Muhammad at-Tahir ibn 'Asyur, cet. 1 (Virginia: Al-Ma'had al'Alami li al-Fikri al-Islami, 1995), 354.

${ }^{35}$ Ali bin Abdul Kafi as-Subuki, al-Ibhaj fi Syarh alMinhaj, vol. 3, cet. 1, (Beirut: Dar al-Kutub al-'Ilmiyyah, 1404 H), 173. 
dan tidak ada yang dapat mengungkap beberapa rahasia yang terkandung di dalamnya kecuali orang-orang yang telah menyelami secara mendalam, induksi yang lama, dan analisis yang benar.

\section{Menggunakan fikih realitas}

Realitas yang sudah berubah, setiap hari selalu menghadirkan problem-problem baru dan melontarkan pertanyaan yang kontras, membuat para peneliti maqasid Alquran harus menyelami kedalaman realitasnya untuk mengklarifikasi rahasianya dan menyerap realitas yang sedang terjadi guna menentukan berbagai kebutuhan yang nyata bagi masyarakat, dan memantau kekhawatiran-kekhawatiran mendesak yang menghantui banyak orang. Berpijak dari situlah perlu kiranya menggandeng fikih realitas untuk mendekati maqasid.

Kenyataan Islam yang memburuk, hidup dalam krisis peradaban yang mencekik di berbagai bidang, seperti politik, ekonomi, sosial, dan budaya, terus menerus membangkitkan perasaan alGhazali dan memenuhi hatinya dengan kesedihan dan kepedihan. Dialah yang menjalani realitasnya dengan semua anggota badannya. Syekh al-Ghazali hidup berinteraksi dengan zamannya, dunianya bercampur dengan agamanya, sehingga kita hampir mencatat buku-bukunya dengan judul-judulnya. Dan dengan topik bukubukunya kita dapat mengenali kapan buku itu ditulisnya. Karena al-Ghazali hidup di masanya dan bergabung dengannya. Hidup dan berinteraksi dengan masanya. Berinteraksi dengan akal yang berafiliasi kepada kebudayaan Islam, dan dengan hati yang penuh dengan kehangatan iman. ${ }^{36}$

Muhammad al-Ghazali berangkat dari realitas sembari merenungkan sumbersumber syar'i, bertanya-tanya kepada sumber-sumber syar'i tersebut, serta meminta pendapat seputar kejadian di sekelilingnya. Semua itu dilakukan Muhammad al-Ghazali supaya dapat memberi keputuasan hukum berdasarkan sumber yang sah, dan membuat batasan yang bernuansa syar'i. Kemudian selanjutnya kembali ke realitas dengan membawa solusi hukum yang tepat sesuai dengan ijtihadnya ${ }^{37}$ dalam kerangka pandangan maqasid yang komprehensif dan mendalam.

Orang yang mengikuti semua karya al-Ghazali, ceramah-ceramahnya, dan

36 Muhammad Yunus, Tajribah asy-Syaikh Muhammad al-Ghazali fi Tajdid al-Fikr al-Islami, cet. 1 (Kairo: Maktabah as-Saqafah ad-Diniyah, 2012), 4.

37 Mahmud Abduh, Muhammad al-Ghazali Da'iyah an-Nahdah al-Islamiyyah, cet. 1 (Beirut: Markaz al-Hadarah li Tanmiyah al-Fikr al-Islami, 2009), 61. 
beberapa dialognya, akan menemukan kedalaman kegundahan peradaban yang membebani umat ini. Muhammad alGhazali melukiskan dengan gambaran suram untuk kehidupan realitasnya. AlGhazali mengungkapkan: "Umat ini merupakan seperlima dari dunia dalam hal sensus. Anda mencarinya ke dalam bidang pengetahuan, namun Anda tidak mendapatinya. Anda mencarinya ke dalam arena produksi, namun Anda juga tidak menemukannya. Anda mencarinya ke dalam model-model moral yang baik, kerjasama yang efektif, kebebasan yang tidak dapat digugat, dan keadilan yang lembut, namun Anda kembali dengan tangan kosong" 38 sementara para musuhnya berlomba-lomba di bidang kehidupan dan menghimpun kekuatan, seperti di bidang ilmiah, militer, dan politik, serta memotongnya dengan langkah-langkah yang menyebabkan kesedihan, keputusasaan, dan frustasi.

Oleh karena itu al-Ghazali menyeru untuk menggunakan fikih realitas dalam rangka menemukan maqasid dan menciptakan perkawinan antara realitas dengan teks Alquran. Sudah seharusnya menjadikan Alquran sebagai kekuatan

${ }^{38}$ Muhammad al-Ghazali, Turasuna al-Fikr fi Mizan asy-Syar'i wa al-'Aqli, 7. penggerak dalam kehidupana kita. Adapun menaruh Alquran di museum-museum dan kantor karena mengharap berkah, atau membuka mushaf dan membaca satu ayat ataupun beberapa ayat, lalu berakhir begitu saja, maka yang demikian itu tidak boleh. ${ }^{39}$

Muhammad al-Ghazali sangat percaya bahwa bermeditasi pada realitas manusia dan memanfaatkan kisah-kisah Alquran yang menceritakan perjalanan umat manusia sepanjang sejarahnya yang mewariskan fikih realitas dapat membantu kita untuk menggunakannya guna mengungkap maqasid Alquran. Muhammad Al-Ghazali mengungkapkan bahwa andaikata mau bermeditasi pada kisah-kisah Alquran, dan mengambil darinya berupa hukum-hukum, sebagaimana halnya mengambil hukum dari ayat wudhu atau ayat mandi mengambil hukum-hukum dari realitas praktis dalam sejarah manusia adalah lebih penting dan lebih pantas karena bersifat universal. Selain itu juga karena berkaitan dengan peradaban-, maka sungguh umat Islam selamanya tidak akan berada dalam kehinaan. ${ }^{40}$

\footnotetext{
39 Muhammad al-Ghazali, Nahwa Tafsirin Maudu'iyyin li Suwar Alquran al-Karim, 60.

40 Al-Ghazali, Kaifa Nata'amalu ma'a Alquran, 183.
} 
4. Penggunaan pandangan dan meditasi adalah perangkat untuk mengungkap maqasid Alquran

Sesungguhnya perenungan yang mendalam dan pertimbangan yang terus menerus terhadap teks-teks Alquran, serta memanfaatkan akal untuk menyibak rahasia-rahasia dan misterinya yang tersembunyi adalah termasuk perangkat lain dari beberapa perangkat prosedural yang dimiliki metode al-Ghazali dalam mengungkap maqasid Alquran. Al-Ghazali percaya bahwa Kitabullah adalah teks yang senantiasa terbuka bagi umat Islam di setiap tempat dan waktu yang membimbing mereka menuju jalan yang paling lurus dalam mengatur urusan mereka, serta menemukan solusi yang efektif untuk masalah mereka yang muncul.

Sebab ketika kehidupan sudah berubah, dan kondisi kehidupan menjadi baru, maka makna refleksi, fakta, dan penyebab juga diperbarui. Ketika kemampual akal semakin aktif dan wawasan manusia dalam menyibak rahasiarahasia alam semesta, maka pintu-pintu perenungan yang bermanfaat akan terbuka baginya, dan misteri makna yang tersembunyi dari kata-kata Alquran akan terungkap. Oleh karena itu menekuni teks- teks Alquran untuk memahami, merenungkan, dan menggali hukum adalah termasuk bentuk taqarrub yang paling agung, perbuatan yang paling mulia, dan kewajiban yang paling wajib. Sesuai firman Allah dalam QS. Shad: 29 yang berbunyi:

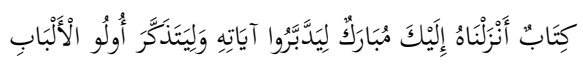

Artinya: Ini adalah sebuah kitab yang Kami turunkan kepadamu penuh dengan berkah supaya mereka memperhatikan ayatayatnya dan supaya mendapat pelajaran orang-orang yang mempunyai fikiran.

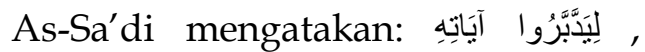
inilah hikmah dari diturunkannya Alquran supaya manusia memperhatikan ayatayatnya, lalu menggali ilmu yang dikandungnya, menganalisa rahasia dan hikmahnya. Sebab dengan memperhatikan dan menganalisa maknanya serta berfikir berulang-ulang, dapat menemukan berkah dan kebaikan. Hal ini menujukkan anjuran untuk memperhatikan Alquran, dan yang demikian itu termasuk ibadah yang paling agung. Pembacaan Alquran yang disertai perenungan itu lebih utama daripada cepat 
membacanya dan tidak dapat menghasilkan tujuan. ${ }^{41}$

Oleh sebab itu perenungan termasuk salah satu perangkat prosedural penting yang diandalkan oleh Muhammad alGhazali dalam mengungkap beberapa tujuan Alquran dengan menerapkan pertimbangan akal terhadap ayat-ayat, terlibat dalam perenungan kata-kata yang ada dalam ayat dan mengeksplorasi maknanya, menganalisis isinya, membandingkan antara ayat yang satu dengan ayat lainnya, serta memberikan pertimbangan yang diperlukan untuk sampai kepada maqasid yang jauh.

Tidak mengherankan, karena Muhammad al-Ghazali sendiri percaya bahwa Alquran telah melepaskan akal sepenuhnya tanpa batas, dan ia juga menyeru agar menggunakan akal, dan memperingatkan untuk tidak mengganggu fungsinya. Al-Ghazali merevolusi kekakuan teks dan literal teks yang mengabaikan peran akal. Al-Ghazali mencela kaum muslimin yang membaca Alquran hanya mengharap berkah dan seakan-akan pengulangan pengucapan kata-kata Alquran tanpa merenungi maknanya adalah

${ }^{41}$ Abdurrahman bin Nasir as-Sa'di, Taisir al-Karim ar-Rahman fi Tafsir Kalam al-Mannan, cet. 2 (Kairo: Maktabah Taufiqiyah, 2015), 782. maksud diturunkannya Alquran. ${ }^{42}$ Pandangan akal telah membimbing alGhazali untuk mengungkap maqasid Alquran yang dimuat dalam ayat-ayat Alquran. Al-Ghazali berfikir panjang bila berhadapan dengan teks-teks Alquran guna menggali makna terdalam dan tujuannya.

\section{Kesimpulan}

Berdasarkan pemaparan di atas, maka dapat diambil benang merah mengenai metode al-Ghazali dalam mengungkap maqasid Alquran. Metode Muhammad al-Ghazali terdiri dari dua aspek, yakni aspek teori dan aspek prosedural praktis dalam kerangka integrasi sisi teori dan praktek. Al-Ghazali telah sampai pada kesimpulan bahwa berbagai metodologi riset pada bidang keilmuan Islam masa lalu tidak mampu menemukan maqasid Alquran atas sebab pandangan yang holistik terhadap maqasid dan hilangnya pandangan komprehensif terhadap Alquran.

Dalam rangka membangun metode baru untuk mendekati maqasid Alquran, maka al-Ghazali menyeru kepada seluruh umat Islam perlunya melampaui semua pembacaan yang parsial, literal, formal, dan

\footnotetext{
${ }^{42}$ Muhammad al-Ghazali, Nazarat fi Alquran, 5.
} 
doktrinal, serta langsung kembali kepada teks Alquran dengan tanpa ada media yang menghalanginya.

Menurut Muhammad al-Ghazali, sebuah metode memberikan urgensi tinggi dalam mendekati maqasid Alquran sampai batas yang mungkin pantas dikatakan bahwa al-Ghazali berpandangan tidak ada maqasid tanpa metode yang jelas ramburambunya dan fitur yang jelas.

Rambu-rambu besar bagi metode alGhazali dalam mendekati maqasid Alquran terdiri dari dua sisi pokok. Sisi pertama adalah aspek teori yang menggambarkan sifat metode dan karakteristiknya. Sementara itu sisi kedua adalah aspek prosedural yang berpijak pada sejumlah perangkat aplikatif. Muhammad al-Ghazali berpijak pada hipotesanya bahwa tafsir tematik Alquran dapat menjadi prosedur awal yang cocok untuk mengungkap maqasid Alquran mengingat adanya korelasi yang kuat di antara keduanya.

Metode induksi mencerminkan salah satu perangkat prosedural yang penting dalam mengungkap maqasid Alquran dengan cara melacak bagian-bagiannya, mengumpulkannya, menganalisisnya, dan mengeluarkan semua korelasi untuk mencapai komprehensifitas yang kompleks.
Al-Ghazali telah mengaplikasikan metodenya itu ke dalam beberapa karyanya yang berbeda-beda, terutama ketiga karyanya; al-Mahawir al-Khamsah li Alquran al-Karim, Nahwa Tafsir Maudu'i li Suwar Alquran al-Karim, dan Kaifa Nata'amalu ma'a Alquran.

\section{Referensi}

1. 'Abduh, Mahmud. Muhammad alGhazali Da'iyah an-Nahdah al-Islamiyyah. cet. 1. Beirut: Markaz al-Hadarah li Tanmiyah al-Fikr al-Islami, 2009.

2. 'Ulwani (al), Taha Jabir. Maqasid asySyariah. cet. 1. Beirut: Dar al-Hadi, 2001.

3. Abduh, Mahmud. Muhammad al-Ghazali Da'iyah an-Nahdah al-Islamiyyah. cet. 1. Beirut: Markaz al-Hadarah li Tanmiyah al-Fikr al-Islami, 2009.

4. Abu as-Sa'ud, Muhammad bin Muhammad. Irsyad al-'Aql as-Salim ila Mazaya Alquran al-Karim (Tafsir Abi as$\left.S a^{\prime} u d\right)$. vol. 5. Beirut: Dar Ihya' at-Turas, t.t.

5. Akademi Bahasa Arab di Kairo. alMu'jam al-Wasit. Beirut: Dar al-Hadis, 1980.

6. Ali Akbar dan Hidayatullah Ismail, Metode Tahfidz al-Qur'an di Pondok Pesantren Kabupaten Kampar, jurnal Ushuluddin, Vol. 24, No. 1 (JanuariJuni, 2016), 92.

7. Badawi, Abdurrahman. Manahij al-Bahs al-'Ilmi. cet. 3. Kuwait: Wakalah alMatbu'ah, 1977.

8. Burghus, Tib. Al-Ab'ad al-Manhajiyyah li Isykaliyah at-Taghyir al-Hadari wa Darurah al-Manhaj. cet. 1. Al-Jaza'ir: Dar al-Yanabi' li an-Nasyr wa al-I'lam, 1993. 
9. Fadlullah, Mahdi. Usul Kitabah al-Bahs wa Qawa'id at-Tahqiq. cet. 2. Beirut: Dar at-Tali' ah, 1998.

10. Fawaid, Ah. Maqasid al-Qur'an dalam Ayat Kebebasan Beragama Menurut Penafsiran Thaha Jabir al-'Alwani, jurnal Madania, Vol. 21, No. 2, (Desember 2017), 113-114.

11. Ghazali (al), Muhammad. Kaifa Nata'amalu ma'a Alquran. cet. 7. Kairo: Nahdah, 2005.

12. . Kaifa Nata'amalu ma'a Alquran. cet. 7. Kairo: Nahdah Misr li at-Tiba'ah, 2005.

13. . Ma'a Allah Dirasat fi ad-Da'wah wa adDu'ah. cet. 4. Damaskus: Dar al-Qalam, 2000.

14. . Nahwa Tafirin Maudu'iyyin li Suwar Alquran al-Karim. cet. 4. Kairo: Dar asySyuruq, 2000.

15. . Nazrat fi Alquran. cet. 5. Kairo: Nahdah Misr, 2005.

16. . Raka'iz al-Iman Baina al-'Aql wa al-Qalb. Kairo: Dar asy-Syuruq, 2001.

17. - Sirru Ta'akhkhur al-'Arab wa alMuslimin. Kairo: Dar ar-Rayyan li atTuras, 1987.

18. . Turasuna al-Fikri fi Mizan asy-Syar'i wa al-'Aql. cet. 5. Kairo: Dar asy-Syuruq, 2003.

19. Husni, Ismail. Nazariyah al-Maqasid 'Inda al-Imam Muhammad at-Tahir ibn 'Asyur. cet. 1. Virginia: Al-Ma'had al‘Alami li al-Fikri al-Islami, 1995.

20. Ibrahimi (al), Muhammad Basyir. Asar al-Imam Muhammad al-Basyir al-Ibrahimi. cet. 1. Beirut: Dar al-Gharb al-Islami, 1997.

21. Mahmud Ghanim, Abdul Hamid. AtTafsir al-Maudu'i, jurnal al-Bayan, vol. 165, (Agustus, 2001), 19.

22. Manzur, Ibnu. Lisan al-'Arab. vol. 14. Beirut: Dar Sadir, 2003.
23. Milal, Yunus. Manhaj asy-Syaikh Muhammad al-Ghazali fi Ta'amulihi ma'a Alquran. Disertasi. Al-Jaza'ir: Universitas al-Jaza' ir, 2010.

24. Muslim, Mustafa. Mabahis fi at-Tafsir alMaudui. cet. 4. Beirut: Dar al-Qalam, 2005.

25. Najjar (al), Abdul Majid. Maqasid Alquran fi Bina al-Fikr al-'Umrani, jurnal Islamiyah al-Ma'rifah, Vol. 89, No. 33 (2017), 88.

26. Rahman, Syahrul. Pro Kontra I'jaz 'Adady dalam al-Qur'an, jurnal Ushuluddin, Vol. 25, No. 1 (JanuariJuni, 2017), 36

27. Sa'di (al), Abdurrahman bin Nasir. Taisir al-Karim ar-Rahman fi Tafsir Kalam al-Mannan. cet. 2. Kairo: Maktabah Taufiqiyah, 2015.

28. Salam, Ahmad. al-Ab'ad al-Manhajiyyah li al-'Amal al-Islami, jurnal al-Ummat, vol. 67, (Maret, 1986), 26.

29. Sami Nasyar (al), Muhammad. Nasy'ah al-Fikr al-Falsafi fi al-Islam. cet. 5, vol. 1. Kairo: Dar al-Ma'arif, 1971.

30. Subuki (al), Ali bin Abdul Kafi. Al-Ibhaj fi Syarh al-Minhaj. vol. 3, cet. 1. Beirut: Dar al-Kutub al-'Ilmiyyah, $1404 \mathrm{H}$.

31. Suyuti (al), Jalaludin. Al-Itqan fi Ulum Alquran. Kairo: Dar as-Salam, 1998.

32. Syatibi (al). Ibrahim bin Musa. AlMuwafaqat fi Usul al-Fiq. vol. 4. Beirut: Dar al-Ma'rifah, t.t..

33. Wahyudi. Tafsir Sufi: Analisis Epistemologi Ta'wil al-Ghazali dalam Kitab Jawahir al-Qur'an, jurnal Ushuluddin, Vol. 26, No. 1 (Januari-Juni, 2018), 45.

34. Yunus, Muhammad. Tajribah asy-Syaikh Muhammad al-Ghazali fi Tajdid al-Fikr alIslami. cet. 1. Kairo: Maktabah asSaqafah ad-Diniyah, 2012. 